\title{
Sufi Commentaries on the Qur'ān in Classical Islam. London - New York, Routledge, 2006, 196 p. (Routledge Studies in the Quran)
}

Ève Feuillebois-Piérunek

\section{(2) OpenEdition}

1 Journals

\section{Édition électronique}

URL : http://journals.openedition.org/abstractairanica/30602

DOI : 10.4000/abstractairanica.30602

ISSN : 1961-960X

Éditeur :

CNRS (UMR 7528 Mondes iraniens et indiens), Éditions de l'IFRI

\section{Édition imprimée}

Date de publication : 15 mai 2008

ISSN : 0240-8910

\section{Référence électronique}

Ève Feuillebois-Piérunek, "Sufi Commentaries on the Qur'ān in Classical Islam. London - New York, Routledge, 2006, 196 p. (Routledge Studies in the Quran) », Abstracta Iranica [En ligne], Volume 29 | 2008, document 300, mis en ligne le 15 septembre 2008, consulté le 26 septembre 2020. URL : http:// journals.openedition.org/abstractairanica/30602; DOI : https://doi.org/10.4000/abstractairanica. 30602

Ce document a été généré automatiquement le 26 septembre 2020.

Tous droits réservés 


\title{
Sufi Commentaries on the Qur'ān in Classical Islam. London - New York, Routledge, 2006, 196 p. (Routledge Studies in the Quran)
}

\author{
Ève Feuillebois-Piérunek
}

1 L'étude s'inscrit dans une longue lignée de recherches occidentales sur le tafsir mystique (Goldziher, Massignon, Nwya) et sur le langage soufi (Corbin, Izutsu, Chittick, Lewisohn, Sells), et se compose de deux parties.

2 La première traite de l'« herméneutique » soufie, comprise ici comme la manière dont les soufis appréhendent la nature du texte coranique, et les sciences et méthodes nécessaires à sa juste compréhension. L'A. examine le Coran comme source de toute connaissance, tout en relevant ses ambiguïtés, étudie la relation entre connaissance mystique et pratique spirituelle, ainsi que les différentes méthodes d'interprétation (recours à l'allusion chez Sarrāj, similitude chez Ġazālī, ǐsāra chez Ibn 'Arabī, ta'wīl chez Nī̌ābūrī et Kāšānī, commentaire sur les sept sens intérieurs de Semnānī), et enfin présente les attaques contre les commentateurs soufis et leurs apologies.

3 La seconde partie présente les commentateurs soufis ici étudiés et leur œuvre (Tustarī, Sollamī, Qušayrī, Ġazālī, Meybodī, Rūzbehān Baqlī, Kāšānī, Nī̌sābūrī), puis compare les différentes interprétations données par ces auteurs de quelques versets représentatifs (Mūsā et al-Hadir, Maryam, Verset de la Lumière). L'A. illustre bien la tension entre le désir légitime de ne pas réduire le Coran à son sens littéral et immédiat, et la crainte qu'une interprétation plus profonde soit entachée d'erreur ou limitée par l'opinion personnelle. Les soufis se réfèrent à l'expérience intérieure des meilleurs d'entre eux pour extraire le sens du Coran, méthode condamnée comme subjective par les docteurs de la Loi (Ibn Taymiyya). L'A. en conclut, avec les auteurs étudiés, que la connaissance des vérités intérieures du Coran est essentiellement une expérience privée qui ne gagne pas à être dévoilée au tout-venant et qui doit donc être transmise oralement dans le cadre d'une relation de maître à disciple, plutôt que par écrit. D'autant plus que ce type 
d'interprétation est constamment en évolution du fait du passage de l'âme à travers les différents états et stations. Elle s'apparente à une guidance intérieure personnalisée qui ne vaut que pour l'individu qui la reçoit, et donc n'a pas vocation à être partagée.

4 Alors que l'herméneutique de tous les ouvrages étudiés est similaire, le langage est tantôt concret et affectif, tantôt symbolique et métaphorique, voire poétique. Les moyens d'expression sont également très diversifiés : anecdotes, récits, homélies, citations, jeux de mots, parallélismes, allégories.

INDEX

Thèmes : 8 . Soufisme

\section{AUTEURS}

\section{ÈVE FEUILLEBOIS-PIÉRUNEK}

Sorbonne Nouvelle-Paris III - Mondes iranien et indien 